\title{
Organics, trust, and credibility: a management and media research perspective
}

\author{
Iris Rittenhofer $^{1}$ and Karen Klitgaard Povlsen ${ }^{2}$
}

\begin{abstract}
Our purpose was to qualify the relations between trust, credibility, and the field of organics by way of creating a dialogue between two independent Organic Research, Development and Demonstration Programme "MultiTrust" subprojects. Both projects explore the explanatory value of trust and credibility for the success of organic labels in the fields of management research and media research. Our key objectives were to critically scrutinize the trust and credibility constructs applied in each of these two fields, to reflect on their explanatory value in the performance of organics from both a management and media perspective, and to set out an agenda for future interdisciplinary research. We conclude that relations between organic products, labels, and consumers are still poorly understood, that the belief in organic labels' direct impact on consumer choices in favor of organic food purchase cannot be supported, and that the explanatory value of trust for the success of organic production remains unproven. We propose for future research to investigate the relevance of credibility and trust for organics in multidisciplinary mixed-methods studies that focus on the emergence of trust, as well as on other social factors impacting the success of organic production. This would best be achieved through interdisciplinary work.
\end{abstract}

Key Words: credibility; customer; management; media; organic food; organic labels; trust

\section{INTRODUCTION}

Our purpose is to qualify the relations between trust, credibility, and the field of organics by way of creating a dialogue between two independent Organic Research, Development and Demonstration Programme (Organic RDD) "MultiTrust" subprojects. Both projects explore the explanatory value of trust and credibility in the use of organic labels in the fields of management research, including organization and marketing, and media research, including communication and rhetoric. Our key objectives are to critically scrutinize the trust and credibility constructs applied in each of these two fields to reflect on their explanatory value in the performance of organics from both a management and media perspective and to set out an agenda for future interdisciplinary research.

The field of organics is complex and contested rather than monolithic. This complexity is often underestimated from a trust perspective in both management research (e.g., Nilsson et al. 2004, Bergström et al. 2005, Pivato et al. 2008) and media and communication studies (Knudsen 2001, Erdem and Swait 2004, Honkanen et al. 2006, Larsen 2006, Kjærnes et al. 2007, Cook et al. 2009, Halkier 2010, Hjelmar 2011, Zachmann and Østby 2011). Both fields handle organics narrowly and focus on food.

Both management and media fields are influenced by the trust concept, as developed by twentieth-century sociologists Georg Simmel (1950), Niklas Luhmann (1999), and Anthony Giddens (1990). Simmel's idea that "trust performs a crucial function in modern societies" (Möllering 2001:411) has been diversely developed within multiple disciplines (Rousseau et al. 1998). The relation between credibility and trust is conceptualized unevenly in the literature (Massey and Kyriazis 2007). Furthermore, the concepts of trust and credibility cannot be adequately clarified by universal categorizations. The relation between trust, credibility, and certified organic food may therefore be best understood in an interdisciplinary comparison. This is a first contribution in this direction.

\section{BACKGROUND AND METHODS}

In both fields, trust research has developed independently of, and prior to, an emergent concern with organics in the 2000s. The management projects examined the use of the concepts trust and credibility and their relationship to the field of organics in a conceptual review of articles published in international peerreviewed management and business journals in the period 1995-2010 (Rittenhofer 2012). Articles with a direct reference to "trust" as a key construct, and to organics, were found in a combined database search and snowball procedure. The databases searched were ELIN, which ceased to exist in 2011, Business Source Complete, Business Source Premier, Science Direct, ABI/ Inform Global, Scopus, and Web of Science. The media research project searched for contributions with a direct reference to trust, and/or credibility, and organics in titles and abstracts in databases on media research, including NCOM 2006-2012, Communication and Mass Media Complete, Communication Abstract, Sociological Abstract, Proquest, Scopus, and Ebsco Host International Encyclopedia of Media Studies, combined with a systematic search in relevant periodicals and a supplementary snowball procedure (Povlsen et al. 2012).

\section{KEY FINDINGS}

\section{Trust in management research}

Simmel's idea that trust performs a fundamental function is extended to the management field. The fundamental agreement that trust is a precondition (Rousseau et al. 1998) for management seems unchallenged by the management field. However, even though it is widespread in management research, the frequency of the term "trust" is no proof of the actual relevance of the phenomenon in practice. As a phenomenon, trust still seems to be empirically intangible (Fiedler 2001). Prior to the early 1990s, trust research took place in fields such as organization studies, social psychology, philosophy, economics, contract law, and marketing (Blomqvist 1997). Later, management research extended its spectrum to include sources such as industrial and 
online marketing (Arnott 2007) or culture (Hofstede et al. 2010). Trust, however, has been studied very little in context-specific terms (Earle 2010).

Many studies apply trust either as a primary construct or as a major component of investigation (Arnott 2007). Trust is taken for granted: it is assumed to be self-evident and self-explanatory. A few studies define trust, yet do not share a definition (e.g., Cowles 1997, Arnott 2007, Blomqvist et al. 2008). The creation or maintenance of trust has hardly been addressed (e.g., Hatanaka et al. 2005, Hatanaka and Busch 2008, Johanson and Vahlne 2009, Prashant and Harbir 2009, Zorn et al. 2012). The concepts of trust and credibility are sometimes applied interchangeably (e.g., Prusak and Cohen 2001, Massey and Kyriazis 2007, Yilmaz and Atalay 2009). In some literature, credibility is seen as a source of trust (e.g., Doney and Cannon 1997, Li 2007, Chen et al. 2010) or as a form of trust (e.g., "credibility trust"; Lindgreen 2003).

Management research developed a trust concept strongly informed by the sociologist Luhmann (1999), who conceptualizes Simmel's idea of functional trust to refer to the individual's need to reduce the complexity of the social environment and to accept related risks to be able to socially interact. Trust is conceptualized as the opposite of "risk" (Fiedler 2001).

The interest in trust in management research exploded in the mid-1990s (Arnott 2007) at a time when business practitioners were starting to assume that trust was a key factor for success (Blomqvist 1997). This function of trust, however, has never been proved (Sako 1991). The management field was influenced to believe that trust existed in every business relationship. Sociopsychological, interpersonal trust relationships were applied to abstract economic interrelationships. Fiedler (2001) suggests that this combined sociological and economic logic draws on new institutional economics (NIE). Previously, management research was influenced by neoclassical economic thinking, which sees rational behavior as key to economic transactions, and trust was believed to be integral to these (Zaheer and Venkatraman 1995). Then it was influenced by NIE, which places "trust" at the center of economic exchange (e.g., Noorderhaven 1996). Recent marketing studies thus reproduce the assumption that trust is one of the major driving factors behind the choice of businesses to take a step toward sustainability (e.g., Aschemann-Witzel 2011).

Very few researchers deal explicitly with the conceptual complexity of trust (e.g., Blomqvist 1997, Li 2007). Some fields, such as environmental risk management, seem to have "coalesced around" context-independent trust dimensions, such as social judgment, intentions, and abilities, and types of functional trust, for instance relational or calculative, personal or impersonal (Earle 2010:541). Scholarly understandings of trust in management research show little cumulative theory building: no "integrated framework to interpret ... the nature, feature, content, process, antecedent and consequence of trust" (Li 2007:421) exists in this context. Despite the fact that the trust phenomenon is not measurable (Fiedler 2001), trust research displays only limited openness to qualitative research ( $\mathrm{Li} 2011)$. In sum, trust is a widely used, but poorly understood, undertheorized, and underresearched phenomenon (Child 2001, Li 2007) in management research.

Trust and credibility in management research in organics

At the turn of the millennium, management research on trust extended its spectrum to include the field of organics. Several of the reviewed studies apply an institutional economics approach (e.g., Moore 2006, Hatanaka and Busch 2008, Franz and Hassler 2010). Few studies, however, have acknowledged the limitations of this approach: Daugbjerg and Halpin (2008) find that an institutional approach to the study of organic schemes in a given society cannot explain the variation in growth between countries. Some organics research has drawn on additional theoretical influences from more contemporary sociological research, such as Giddens (1990), e.g., Moore (2006) and Sønderskov and Daugbjerg (2011); and Bourdieu (1986), e.g., Prusak and Cohen (2001), Hatanaka et al. (2005), and Sodano et al.(2008). Nevertheless, studies continue to corroborate faith in the importance of trust for economic success in the field of organics. Pivato et al. (2008:3), for example, explicitly "believe" in trust as an intermediary between corporations and customers, and thus as highly important for the economic success of organic food. The antecedents and emergence of trust have been neither researched nor theorized specifically in the context of organics.

The weaknesses of the trust concept in management research further parallel those in organics research. Trust is described by dimensions (e.g., Kottila and Rönni 2008), and the terms "trust" and "confidence" are often applied synonymously (e.g., Moore 2006, Sønderskov and Daugbjerg 2011). With a few exceptions (e.g., Kottila and Rönni 2008), the trust concept is not clearly defined and is applied as if it were self-evident (e.g., Claro and de Oliveira Claro 2004, Nilsson et al. 2004, Hatanaka et al. 2005, Halberg et al. 2006, Daugbjerg and Halpin 2008, Hatanaka and Busch 2008, Franz and Hassler 2010, Zorn et al. 2012). Many studies of organics are quantitative (e.g., Ward et al. 2004, Perrini et al. 2010). In sum, management research has developed a way of dealing with trust that is independent of organics and that has become normalized.

\section{The relations between trust, credibility, and organics in management research}

"Trust" and "credibility" are either applied synonymously (e.g., Nilsson et al. 2004) or causally where credibility is perceived as the source of trust, and trust as a direct function of credibility (e.g., Knight et al. 2007, Perrini et al. 2010). Most studies on trust and organics reproduce the assumed importance of trust in an exchange context (e.g., Aarset et al. 2004). Trust issues in business-to-business relationships (Claro and de Oliveira Claro 2004), organic food chains (Kottila and Rönni 2008), and noncertified organic produce (Moore 2006), and the impact of trust (Nilsson et al. 2004) on consumer perceptions of the building blocks of organic schemes, i.e., traceability, transparency, or ownership, have been less well researched. Few studies apply the assumed importance of trust to actors in organic commodity chains (Hatanaka et al. 2005) or to the dependence of third-party certifiers on accreditation bodies (Hatanaka and Busch 2008). Most often, the exchange context is composed of organic labels (e.g., Nilsson et al. 2004, Padel and Foster 2005, Sønderskov and Daugbjerg 2011) and consumer interests and behaviors (e.g., Padel and Foster 2005, Thøgersen 2005, Moore 2006, Hampton et al. 2007, Pivato et al. 2008, Auger et al. 2010, Eckhardt et al. 2010, Gielissen 2011, Sønderskov and Daugbjerg 2011). Consumer trust is inferred if organic products sell successfully (e.g., Getz and Shreck 2006).

Trust issues affecting the producers, suppliers, or processors of organic food have hardly been studied, whereas in management 
studies the impact of trust on consumer choice has been strongly emphasized in explaining the economic success of labeled organic products. "The literature assumes that trust [...] is translated into a consumer's intention to purchase" (Pivato et al. 2008:4). We therefore propose that the producer-consumer divide reflects a divide in economic logic between neoclassical "rationality" and NIE socio-psychological, interpersonal drivers. Studies emphasize the impact of nonrational, "soft" factors on consumer choice: consumer faith (Ward et al. 2004), consumer values (Moore 2006, Pivato et al. 2008), the creation of meaningful knowledge (Franz and Hassler 2010), the perception of value added (Claro and de Oliveira Claro 2004), or the interpretation of organic purchases as an expression of consumers' personal values (Fotopoulos and Krystallis 2002). In this perspective, the predominant research focus on organic labels has contributed to a reductive image of organics as a consumer economy based on trust.

Research into state-controlled organic labels (e.g., Ward et al. 2004) such as the Danish "ø-mærke" tacitly assumes that trust in the state is a currency that is invested in organic labels in return for increased demand for agricultural products and related profit. This assumption is challenged, however, by several studies. In contemporary "posttrust" societies, citizens no longer fully trust regulators (e.g., Aarset et al. 2004, Moore 2006) or industry (Earle 2010); the superiority of the state label is not clear cut (Sønderskov and Daugbjerg 2011). Some studies suggest that there is greater trust in private (Perrini et al. 2010) or independent certifications (Padel and Foster 2005) than in state labels, and in personal assurance rather than in certification (Moore 2006). Few studies (Ward et al. 2004, Sodano et al. 2008) have investigated trust in state labels compared with alternative certifications and noncertified food. A one-sided focus on the role of statecontrolled labels is of limited value for understanding organic growth because it overlooks factors like governance structures; internationalized standards for food safety, quality, and organics; and the increasing private development of standards by bodies independent of buyers or governments (Hatanaka et al. 2005).

The frequent single-country or regional studies (e.g., Padel and Midmore 2005, Getz and Shreck 2006, Moore 2006, Hampton et al. 2007, Hatanaka and Busch 2008, Pivato et al. 2008, Franz and Hassler 2010, Sønderskov and Daugbjerg 2011) do not reflect complex and internationalized governance structures arising within societies. Management studies are reductive in their approach to organics. Political and economic changes "have increasingly constrained the capability of states to regulate food and agriculture," and more and more, the state is cooperating with both corporations and private regulatory bodies (Hatanaka and Busch 2008:74-76).

In sum, a universalized "trust" concept and a functionalist credibility-trust relation have been brought to bear in the study of organics. Our findings suggest one area in which trust is widely assumed to be a major building block: in simplistic understandings of organic customer-business relationships.

\section{Trust and credibility in media research}

Unlike management studies research, media and communication research differentiates between trust and credibility. The understanding of trust in this field is based on sociological theories that distinguish between trust in "abstract systems"
(Simmel 2008), such as media institutions, and trust between persons and in face-to-face communication (Giddens 1990, Luhmann 1999). The system of organic labels is an abstract one.

Following the tradition of classical rhetoric, credibility is conceptualized independently of trust. Acceptance of the positive moral character or ethos of the content producer, e.g., websites or labels, is a precondition for users to build credibility for media (Hoff-Clausen 2002, 2008). Two main definitions of credibility exist. Aristotle defines credibility as an ethos of rationality that builds a logical argument. Cicero defines credibility as an ethos of sympathy that can build goodwill among the audience. In this definition, the development of credibility over time is emphasized: credibility is the starting point of negotiation processes that may potentially lead to cultivating a feeling of trust. In this view, trust is an emergent concept (Amossy 2001, Hoff-Clausen 2008).

Audiences of traditional mass media and users of digital network media construct and lend credibility to media producers and messages such as the organic label. It is the media user who decides which message is credible and sympathetic (Hyde 2004, HoffClausen 2008). This decision is based on experience and ongoing communication. The media producer can try to act honestly and coherently but cannot control the process or its outcome (HoffClausen 2008, Simmel 2008). Trust is defined in relation to credibility as the result of a process between communicator, message, and audience, with the audience as the decisive agent.

In media research, credibility is understood as a precondition of trust. The credibility of media or labels emerges over time if the media are well known and coherent, and if the media content supports real-life experiences and moral norms (Knudsen 2001, Halkier and Holm 2004, Hoff-Clausen 2008, Halkier 2010). The process of creating trust, however, is neither predictable nor controllable: it is the media user who negotiates and decides whether the media, e.g., the organic labels, are credible and thus to be trusted in the long run. Media research indicates that trust is a relational phenomenon, emergent from complex communicative and social relations.

Emergent trust effectively reduces complexity. If we trust, we do not want to know all the details or pros and cons (Simmel 1990, 2008, Luhmann 1999, Bildtgård 2008, Zachmann and Østby 2011). Once trust has been established, people tend to neglect contradictory information (Lazarsfeld et al. 1944, Zagata and Lostak 2012). The perceived credibility of media and media content solidifies trust. This impacts future behavior (Stzompka 1999, Knudsen 2001, Hoff-Clausen 2008, Simmel 2008), such as the acceptance of selected uncertainties (Lamine 2005, Zagata and Lostak 2012).

Contemporary societies are media saturated. Most organizations and production companies have developed their own powerful media institutions and media divisions (Krotz 2007, Hjarvard 2009, Lundby 2009). Media are increasingly commercialized, and media production and media use are embedded in all production, distribution, or consumption processes, including organic production retail and consumption (Couldry and Hepp 2013 , Jensen 2013). The more intensive societal media saturation and commercialization becomes, the more credibility and trust mediate communication needs. 


\section{The relations between trust, credibility, and organics in media research}

The relation between credibility and trust is a continuum, dependent on media users' active interpretations and reflexivity (Giddens 1990, Bordum and Wenneberg 2001, Knudsen 2001, Hoff-Clausen 2002, 2008, Bildtgård 2008). This has important implications for building consumer trust, i.e., for the attempt to create conditions that allow for consumer trust in third-partycertified organic labels (Hatanaka et al. 2005, Kimura 2010). Labels can be print media or digital media. There has been hardly any media research on organic labels, with the consequence that we know little about the perceived credibility of, e.g., organic labels. However, some consumer studies suggest that the credibility of organic labels varies (Naspetti and Zanoli 2009, Kimura 2010, Janssen and Hamm 2012).

Media communication is not the simple transmission of information. Media use as an everyday activity implies ongoing interpretations between media and media users (Lazarsfeld et al. 1944, Hall 1980, Drotner et al. 1996, Povlsen 1999). This includes the use of organic labels. Media use is an active interpretative process (Schrøder et al. 2003). Isolating the role of media and segregating the impact of organic labels is hardly possible. Studies show that trust is an important factor for the growth in consumption of organic food in Denmark (Smed et al. 2013) but cannot explain how trust emerges. The rather scarce research in mediated organics in Denmark (e.g., Larsen 2006, Halkier 2010, Hjelmar 2011) challenges the assumption that there is a causal relation between labels and growth in organics (Kjærnes et al. 2007, Hjelmar 2011).

Studies demonstrate that consumer trust in organic labels varies from country to country and from label to label (Hjelmar 2011, Janssen and Hamm 2012, Zagata and Lostak 2012). A UK study shows that consumers there are skeptical about organic labels (Cook et al. 2009). Comparative cross-cultural studies on the relations between the organic label, perceived credibility, and trust demonstrate that experience is not transferable from one European state to another (Aarset et al. 2004, Baker et al. 2004, Berg et al. 2005, Naspetti and Zanoli 2009). No shared perception of organics or of organic labels exists. Furthermore, many studies have researched labels as single media, reducing them to vehicles for the transmission of information (Aarset et al. 2004, Baker et al. 2004, Berg et al. 2005). No comparative study has conceptualized organic labels as embedded in the complex mediated communications in which consumers and media users engage in daily life.

A single study (Cook et al. 2009) includes stakeholders at all stages of the organic supply and value chain, but it is limited to the UK. Comparing the packaging of organic and conventional food, the study shows that the printed packaging of conventional products carries more factual texts, whereas organic products carry more emotive texts and pictures. Producers and retailers believe that consumers want pathos, but consumers may prefer ethos and facts (Cook et al. 2009). Thus, organic food packaging communicates pathos rather than ethos, which may limit its consumer credibility (Hoff-Clausen 2008).

In fact, consumers negotiate between competing media messages. Hjelmar (2011), Rosen (2010), and Zanoli and Naspetti (2002) show that European consumer interpretations of organic labels reflect differing priorities in health, animal welfare, environmental issues, taste, and quality. Quantitative and qualitative studies from other cultures suggest the same (Chen 2007, RoitnerSchobesberger et al. 2008, Akaichi et al. 2012). Media users (Lolk and Horst 2001, Tulloch and Lupton 2003, Reilly 2006) and consumers (Bildtgård 2008, De Krom 2009, Jokinen et al. 2012) tend to give high credibility to light entertainment, e.g., to television chefs. This suggests that negotiating media, rather than single media, impact choices and consumption habits. Eden focuses exclusively on how organic labels change consumer behavior. She criticizes the belief in labels as a "knowledge fix" (Eden et al. 2008:1) and proposes conceptualizing organic labels as "boundary objects" (Eden 2011:179) that intermediate between producers and consumers. Labels tend to be reduced to a vehicle for marketing and for transmitting information (Chen 2007, Roitner-Schobesberger et al. 2008, Eden 2011, Hjelmar 2011, Akaichi et al. 2012). However, qualitative research shows that consumers perceive organic labels as advertisements, not neutral intermediaries, and many respondents therefore approach labels with critical reflection perceiving them as not credible (Cook et al. 2009, Finnemann et al. 2012, Povlsen 2015).

Research reveals a shared tendency in the media for a lack of critical journalism, hard facts, and more complex knowledge about organics (Cahill et al. 2010). Media content analyses show that the media almost exclusively represent organic food as a positive alternative to conventional food (Lockie 2006, Cahill et al. 2010). Organic signifies "good" production, whereas conventional signifies "bad." Food scares reported in the media are most often about conventional food (Lolk and Horst 2001, Tulloch and Lupton 2003, Ansell and Vogel 2006). A Czech study reveals that once credibility and trust in organic products is established, news items about fraud and food scares are assigned to the lack of credibility of news media (Zagata and Lostak 2012). Media research findings thus suggest that increased information about organic standards and certification processes will not impact consumers' decisions in preferring organic products.

In sum, because of media saturation in society, it is difficult to isolate the impact on consumer behavior of labels, popular entertainment, or media news. Media use related to food is embedded in daily practices, as documented in a recent mixedmethods study (Povlsen 2015). Finnemann et al. (2012), in a survey from 2009, revealed that there was no correlation between distrust in conventional food and trust in organic food. In the qualitative study (Povlsen 2015), the 16 respondents all mentioned the media as an important factor affecting their food preferences, despite their individualized media-use patterns, highly diverse perceptions of organic labels, and diverse motivations to trust organic labels. Nevertheless, a pattern did exist in the relationship between media use, credibility, and trust in organics. In the process of building credibility toward organics, young adults had relatively mainstream media use but in the interview often emphasized positive media narrations on organics. Older respondents, who already trusted organic food, chose media that confirmed their preferences, e.g., lifestyle television about organic living or websites with organic recipes. They neglected media content that was critical of organic production, e.g., in television news (Povlsen 2015).

In sum, media use has some impact on creating credibility toward organics, while trust in organics influences people's media use. The media saturation of society makes it difficult to isolate the 
impact of labels, popular entertainment, and media news on consumer behavior.

\section{DISCUSSION}

Sociological influences in both management and media research are combined in diverse ways. In management, they are combined with economic thinking, and in media research with rhetoric. Accordingly, management research reduces organics to customer-business relationships, in which business is represented by organic labels and customer purchase decisions are a function of trust. The trust framework applied in management disregards a process understanding of trust creation and of social impact factors other than trust. The field could leverage media studies' conceptualization of interactive customers embedded in everyday life in a media-saturated society. The field contributes to understanding how credibility may emerge for organic labels in interactions. It challenges the reductive, functional understanding of trust in management research because recent studies show that the emergence of consumer trust may be neither controlled nor foreseen. Media research, on the other hand, could leverage management's insights into business aspects.

Media and marketing research would benefit from studying crossmedia appearances of organic labels on packaging, on the Internet, on television, or in print media empirically. Future research should also provide empirically supported understandings of how media users and consumers actually negotiate the credibility of media messages such as labels in an everyday context of cross-media use. Management and media studies would greatly benefit from more research in organics extended to the diverse and competing accreditation and certification schemes, as well as to noncertified organic products and nonfood products. A process approach to a differentiated credibility-trust relation would be of great importance to future interdisciplinary research. Interdisciplinary research has the potential to create insightful contextual knowledge on the emergence of trust and on other social factors impacting the still poorly understood relations between organic products, labels, and customers.

\section{CONCLUSION}

We contribute insights that demonstrate a need for organic research to further develop an interdisciplinary understanding of the relation between trust, credibility, and certified organic food and to consider factors other than trust and credibility that could potentially improve the performance of organics. The key insight that arises from the dialogue between a management and a media research project on the explanatory value of trust and credibility is that the widely shared assumption that organic labels directly impact consumer choices in favor of organic food purchase cannot be supported. International regulations of food and organic standards and the coexistence of diverse public and private organic standards are largely ignored. Similarly, little attention is paid to consumers' diverse cross-media usage and their negotiations in complex media landscapes where it becomes impossible to single out the impact of a single type of media. Although both fields employ a terminology of credibility and trust, there are no shared definitions of trust and credibility. Although media research provides a process understanding of trust, which is more complex than how trust is understood and treated in management research, the concept remains poorly understood in both fields. It continues to be applied to reductive understandings of organics, and the explanatory value of trust for the success of organic production still remains unproven.

Responses to this article can be read online at: http://www.ecologyandsociety.org/issues/responses. $\mathrm{php} / 7169$

\section{Acknowledgments:}

This work is integrated into the research of the interdisciplinary Organic RDD project MultiTrust (http://multitrust.orgl) financed by the Danish Ministry of Food, Agriculture and Fisheries 2011-2013.

\section{LITERATURE CITED}

Aarset, B., S. Beckmann, E. Bigne, M. Beveridge, T. Bjorndal, J. Bunting, P. McDonagh, C. Mariojouls, J. Muir, A. Prothero, L. Reisch, A. Smith, R. Tveteras, and J. Young. 2004. The European consumers' understanding and perceptions of the "organic" food regime. The case of aquaculture. British Food Journal 106 (2):93-105. http://dx.doi.org/10.1108/00070700410516784

Akaichi, F., R. M. Nayga Jr., and J. M. Gil. 2012. Assessing consumers' willingness to pay for different units of organic milk: evidence from multiunit auctions. Canadian Journal of Agricultural Economics 60(4):469-494. http://dx.doi.org/10.1111/ j.1744-7976.2012.01254.x

Amossy, R. 2001. Ethos at the crossroads of disciplines: rhetoric, pragmatics, sociology. Poetics Today 22(1):1-23. http://dx.doi. org/10.1215/03335372-22-1-1

Ansell, C., and D. Vogel, editors. 2006. What's the beef? The contested governance of European food safety. MIT Press, Cambridge, Massachusetts, USA.

Arnott, D. C. 2007. Trust - current thinking and future research. European Journal of Marketing 41(9-10):981-987. http://dx.doi. org/10.1108/03090560710773291

Aschemann, J. 2011. Flashlight: supporting sustainable food entrepreneurs. CORPUS: The SCP Knowledge Hub, Seventh Framework Program of the European Commission, Berlin, Germany. [online] URL: http://www.scp-knowledge.eu/sites/ default/files/KU_Flashlight_Supporting_Sustainable_Food_Entrepreneurs $0 . p d f$

Auger, P., T. M. Devinney, J. J. Louviere, and P. F. Burke. 2010. The importance of social product attributes in consumer purchasing decisions: a multi-country comparative study. International Business Review 19:140-159. http://dx.doi. org/10.1016/j.ibusrev.2009.10.002

Baker, S., K. E. Thompson, J. Engelken, and K. Huntley. 2004. Mapping the values driving organic food choice: Germany vs the UK. European Journal of Marketing 38(8):995-1012. http://dx. doi.org/10.1108/03090560410539131

Berg, L., U. Kjaernes, E. Ganskau, V. Minina, L. Voltchkova, B. Halkier, and L. Holm. 2005. Trust in food safety in Russia, Denmark and Norway. European Societies 7(1):103-129. http:// dx.doi.org/10.1080/1461669042000327045 
Bergström, K., C. Solér, and H. Shanahan. 2005. Professional food purchasers' practice in using environmental information. British Food Journal 107(5):306-319. http://dx.doi. org/10.1108/00070700510596893

Bildtgård, T. 2008. Trust in food in modern and late-modern societies. Social Science Information 47(1):99-128. http://dx.doi. org/10.1177/0539018407085751

Blomqvist, K. 1997. The many faces of trust. Scandinavian Journal of Management 13(3):271-286. http://dx.doi.org/10.1016/ $\underline{\mathrm{S} 0956-5221(97) 84644-1}$

Blomqvist, K., P. Hurmelinna-Laukkanen, N. Nummela, and S. Saarenketo. 2008. The role of trust and contracts in the internationalization of technology-intensive Born Globals. Journal of Engineering and Technology Management 25:123-135. http://dx.doi.org/10.1016/j.jengtecman.2008.01.006

Bordieu, P. 1986. The forms of capital. Pages 241-258 in J. Richardson, editor. Handbook of theory and research for the sociology of education. Greenwood, New York, New York, USA.

Bordum, A., and S. B. Wenneberg, editors. 2001. Det handler om tillid. Samfundslitteratur, Copenhagen, Denmark.

Cahill, S., K. Morley, and D. A. Powell. 2010. Coverage of organic agriculture in North American newspapers: media: linking food safety, the environment, human health and organic agriculture. British Food Journal 112(7):710-722. http://dx.doi. org/10.1108/00070701011058244

Chen, M.-F. 2007. Consumer attitudes and purchase intentions in relation to organic foods in Taiwan: moderating effects of foodrelated personality traits. Food Quality and Preference 18 (7):1008-1021. http://dx.doi.org/10.1016/j.foodqual.2007.04.004

Chen, T.-Y. , T.-L. Yeh, and H.-C. Yeh. 2011. Trust-building mechanisms and relationship capital. Journal of Relationship Marketing 10(3):113-144. http://dx.doi.org/10.1080/15332667.2$\underline{011.596471}$

Child, J. 2001. Trust-the fundamental bond in global collaboration. Organizational Dynamics 29(4):274-288. http://dx. doi.org/10.1016/S0090-2616(01)00033-X

Claro, D. P., and P. B. de Oliveira Claro. 2004. Coordinating B2B cross-border supply chains: the case of the organic coffee industry. Journal of Business \& Industrial Marketing 19(6):405-414.

Cook, G., M. Reed, and A. Twiner. 2009. "But it's all true!": commercialism and commitment in the discourse of organic food promotion. Text and Talk 29(2):151-173.

Couldry, N., and A. Hepp. 2013. Conceptualizing mediatization: contexts, traditions, arguments. Communication Theory 23:191-202. http://dx.doi.org/10.1111/comt.12019

Cowles, D. L. 1997. The role of trust in customer relationships: asking the right questions. Management Decision 35(4):273-282. http://dx.doi.org/10.1108/00251749710169657

Daugbjerg, C., and D. Halpin. 2008. Sharpening up research on organics: why we need to integrate sectoral policy research into mainstream policy analysis. Policy Studies 29(4):393-404. http:// dx.doi.org/10.1080/01442870802482125
De Krom, M. P. M. M. 2009. Understanding consumer rationalities: consumer involvement in European food safety governance of avian influenza. Sociologica Ruralis 49:1-19. http:// dx.doi.org/10.1111/j.1467-9523.2008.00474.X

Doney, P. M., and J. P. Cannon. 1997. An examination of the nature of trust in buyer-seller relationships. Journal of Marketing 61(2):35-51. http://dx.doi.org/10.2307/1251829

Drotner, K., K. B. Jensen, I. Poulsen, and K. C. Schroeder. 1996. Medier og kultur: en grundbog $i$ medieanalyse og medieteori. Borgen, Copenhagen, Denmark.

Earle, T. C. 2010. Trust in risk management: a model-based review of empirical research. Risk Analysis 30(4):541-574. http://dx.doi. org/10.1111/j.1539-6924.2010.01398.x

Eckhardt, G. M., R. Belk, and T. M. Devinney. 2010. Why don't consumers consume ethically? Journal of Consumer Behaviour 9:426-436. http://dx.doi.org/10.1002/cb.332

Eden, S. 2011. Food labels as boundary objects: how consumers make sense of organic and functional foods. Public Understanding of Science 20(2):179-194. http://dx.doi.org/10.1177/0963662509336714

Eden, S., C. Bear, and G. Walker. 2008. Understanding and (dis) trusting food assurance schemes: consumer knowledge and the 'knowledge fix'. Journal of Rural Studies 24:1-14. http://dx.doi. org/10.1016/j.jrurstud.2007.06.001

Erdem, T., and J. Swait. 2004. Brand credibility, brand consideration, and choice. Journal of Consumer Research 31:191-198. http://dx.doi.org/10.1086/383434

Fiedler, M. 2001. Vertrauen ist gut, Kontrolle ist teuer: Vertrauen als Schlüsselkategorie wirtschaftlichen Handelns. Geschichte und Gesellschaft: Zeitschrift für historische Sozialwissenschaft 27:576-592.

Finnemann, N. O., P. Jauert, J. L. Jensen, R. Marselis, K. K. Povlsen, and A. S. Sørensen. 2012. The media menus of Danish Internet users 2009. Danish National Research Council: Humanities, Aarhus, Denmark. [online] URL: http:// changingborders.au.dk/wp-content/uploads/2012/05/The-MediaMenus-of-Danish-Internet-Users-2009.pdf

Fotopoulos, C., and A. Krystallis. 2002. Organic product avoidance: reasons for rejection and potential buyers' identification in a countrywide survey. British Food Journal 104 (3-5):233-260. http://dx.doi.org/10.1108/00070700210425697

Franz, M., and M. Hassler. 2010. The value of commodity biographies: integrating tribal farmers in India into a global agrofood network. AREA 42(1):25-34. http://dx.doi.org/10.1111/ j.1475-4762.2009.00893.x

Getz, C., and A. Shreck 2006. What organic and Fair Trade labels do not tell us: towards a place-based understanding of certification. International Journal of Consumer Studies 30 (5):490-501. http://dx.doi.org/10.1111/j.1470-6431.2006.00533.x

Giddens, A. 1990. The consequences of modernity. Polity, Cambridge, UK.

Gielissen, R. B. 2011. Why do consumers buy socially responsible products? International Journal of Business and Social Science 2 (3):21-35. 
Halberg, N., H. F. Alrøe, M. T. Knudsen, and E. S. Kristensen, editors. 2006. Global development of organic agriculture: challenges and prospects. CABI, Wallingford, UK. http://dx.doi. org/10.1079/9781845930783.0000

Halkier, B. 2010. Consumption challenged. Food inmedialised every day lives. Ashgate, Farnham, UK.

Halkier, B., and L. Holm. 2004. Tillid til mad - forbrug mellem dagligdag og politisering. Dansk Sociologi 15:9-26.

Hall, S. 1980 [1973]. Encoding/decoding. Pages 128-138 in S. Hall, D. Hobson, A. Lowe, and P. Willis, editors. Culture, media, language: working papers in cultural studies 1972-79. Hutchinson, London, UK.

Hampton, R., I. Fromm, and N. Bonani. 2007. International trade, consumer behavior and trust: factors affecting agribusinesses in developing countries. International Food and Agribusiness Management Review 10(3):113-118.

Hatanaka, M., C. Bain, and L. Busch. 2005. Third-party certification in the global agrifood system. Food Policy 30:354-369. http://dx.doi.org/10.1016/j.foodpol.2005.05.006

Hatanaka, N., and L. Busch. 2008. Third-party certification in the global agrifood system: an objective or socially mediated governance mechanism? Sociologia Ruralis 48(1):73-91. http://dx. doi.org/10.1111/j.1467-9523.2008.00453.x

Hjarvard, S. 2009. Samfundets medialisering. NordiconInformation 31(1-2):5-35.

Hjelmar, U. 2011. Consumers' purchase of organic food products. A matter of convenience and reflexive practices. Appetite 56 (2):336-344. http://dx.doi.org/10.1016/j.appet.2010.12.019

Hoff-Clausen, E. 2002. Set gennem nettet. Samfundslitteratur, Copenhagen, Denmark.

Hoff-Clausen, E. 2008. Online ethos. Samfundslitteratur, Copenhagen, Denmark.

Hofstede, G. J., M. Fritz, M. Canavari, E. Oosterkamp, and G.J. van Sprundel. 2010. Towards a cross-cultural typology of trust in B2B food trade. British Food Journal 112(7):671-687. http://dx. doi.org/10.1108/00070701011058226

Honkanen, P., P. Verplanken, and S. O. Olsen. 2006. Ethical values and motives driving organic food choice. Journal of Food Behaviour 5:420-430.

Hyde, M. J., editor. 2004. The ethos of rhetoric. University of South Carolina Press, Columbia, South Carolina, USA.

Janssen, M., and U. Hamm. 2012. Product labelling in the market for organic food: consumer preferences and willingness-to-pay for different organic certification logos. Food Quality and Preference 25(1):9-22. http://dx.doi.org/10.1016/j.foodqual.2011.12.004

Jensen, K. B. 2013. Definitive and sensitizing conceptualizations of mediatization. Communication Theory 23:203-222. http://dx. doi.org/10.1111/comt.12014

Johanson, J., and J.-E. Vahlne. 2009. The Uppsala internationalization process model revisited: from liability of foreignness to liability of outsidership. Journal of International Business Studies 40:1411-1431. http://dx.doi.org/10.1057/ jibs.2009.24
Jokinen, P., S. Kupsala, and M. Vinnari. 2012. Consumer trust in animal farming practices - exploring the high trust of Finnish consumers. International Journal of Consumer Studies 36 (1):106-113. http://dx.doi.org/10.1111/j.1470-6431.2011.00996.x

Kimura, A. H. 2010. Between technocracy and democracy: an experimental approach to certification of food products by Japanese consumer cooperative women. Journal of Rural Studies 26(2):130-140. http://dx.doi.org/10.1016/j.jrurstud.2009.09.007

Kjærnes, U., M. Harvey, and A. Warde. 2007. Trust in food: a comparative and institutional analysis. Palgrave Macmillan, New York, New York, USA.

Knight, J., D. Holdsworth, and D. Mather. 2007. Determinants of trust in imported food products: perceptions of European gatekeepers. British Food Journal 109(10):792-804. http://dx.doi. org/10.1108/00070700710821331

Knudsen, M. 2001. Krop og suverænitet - om to måder at skabe tillid på. Pages 15-24 in A. Bordum and B. S. Wenneberg, editors. Det handler om tillid. Samfundslitteratur, Copenhagen, Denmark.

Kottila, M. R., and P. Rönni. 2008. Collaboration and trust in two organic food chains. British Food Journal 110(4-5):376-394.

Krotz, F. 2007. Mediatisierung. Fallstudien zum Wandel der Kommunikation. VS Verlag für Sozialwissenschaften, Wiesbaden, Germany.

Lamine, C. 2005. Settling shared uncertainties: local partnerships between producers and consumers. Sociologia Ruralis 45 (4):324-345. http://dx.doi.org/10.1111/j.1467-9523.2005.00308.x

Larsen, C. S. 2006. Italesattelser af økologisk mad. Sociologisk Institut, Copenhagen, Denmark.

Lazarsfeld, P., B. Berelson, and H. Gaudetet. 1944. The people's choice. Columbia University Press, New York, New York, USA.

Li, P. P. 2007. Towards an interdisciplinary conceptualization of trust: a typological approach. Management and Organization Review 3(3):421-445. http://dx.doi.org/10.1111/j.1740-8784.2007.00081. $\underline{x}$

Li, P. P. 2011. The rigour-relevance balance for engaged scholarship: new frame and new agenda for trust research and beyond. Journal of Trust Research 1(1):1-21. http://dx.doi. org/10.1080/21515581.2011.550718

Lindgreen, A. 2003. Trust as a valuable strategic variable in the food industry: different types of trust and their implementation. British Food Journal 105(6):310-327. http://dx.doi. org/10.1108/00070700310481694

Lockie, S. 2006. Capturing the sustainability agenda: organic foods and media discourses on food scares, environment, genetic engineering, and health. Agriculture and Human Values 23 (3):313-323. http://dx.doi.org/10.1007/s10460-006-9007-3

Lolk, M., and M. Horst. 2001. Den nødvendige overreaktion en fortælling om tillid og risiko i et medieperspektiv. Pages 139-148 in A. Bordum and B. S. Wenneberg, editors. Det handler om tillid. Samfundslitteratur, Copenhagen, Denmark. 
Luhmann, N. 1999(1968). Tillid - en mekanisme til reduktion af social kompleksitet. (Vertrauen). Hans Reitzels Forlag, Copenhagen, Denmark.

Lundby, K. 2009. Mediatization. Concept, changes, consequences. Peter Lang, New York, New York, USA.

Massey, G. R., and E. Kyriazis 2007. Interpersonal trust between marketing and R\&D during new product development projects. European Journal of Marketing 41(9/10):1146-1172. http://dx.doi. org/10.1108/03090560710773381

Möllering, G. 2001. The nature of trust: from Georg Simmel to a theory of expectation, interpretation and suspension. Sociology 35(2):403-420. http://dx.doi.org/10.1177/S0038038501000190

Moore, O. 2006. Understanding postorganic fresh fruit and vegetable consumers at participatory farmer's markets in Ireland: reflexivity, trust and social movements. International Journal of Consumer Studies 30(5):416-426. http://dx.doi.org/10.1111/ j.1470-6431.2006.00537.x

Naspetti, S., and R. Zanoli. 2009. Organic food quality and safety perception throughout Europe. Journal of Food Products Marketing 15(3):249-266. http://dx.doi.org/10.1080/10454440902908019

Nilsson, H., B. Tuncer, and A. Thidell. 2004. The use of ecolabeling like initiatives on food products to promote quality assurance - is there enough credibility? Journal of Cleaner Production 12:517-526. http://dx.doi.org/10.1016/S0959-6526 (03)00114-8

Noorderhaven, N. G. 1996. Opportunism and trust in transaction cost economics. Pages 105-128 in J. Groenewegen, editor. Transaction cost economics and beyond. Kluwer Academic, Boston, Massachusetts, USA. http://dx.doi.org/10.1007/978-94$\underline{-009-1800-9 \quad 6}$

Padel, S., and C. Foster. 2005. Exploring the gap between attitudes and behavior: understanding why consumers buy or do not buy organic food. British Food Journal 107(8):606-625. http://dx.doi. org/10.1108/00070700510611002

Padel, S., and P. Midmore. 2005. The development of the European market for organic products: insights from a Delphi study. British Food Journal 107(8):626-646. http://dx.doi. org/10.1108/00070700510611011

Perrini, F., S. Castaldo, N. Misani, and A. Tencati. 2010. The impact of corporate social responsibility associations on trust in organic products marketed by mainstream retailers: a study of Italian consumers. Business Strategy and the Environment 19:512-526. http://dx.doi.org/10.1002/bse.660

Pivato, S., N. Misani, and A. Tencati. 2008. The impact of corporate social responsibility on consumer trust: the case of organic food. Business Ethics: A European Review 17(1):3-12. http://dx.doi.org/10.1111/j.1467-8608.2008.00515.x

Povlsen, K. K. 1999. Beverly Hills 2010. Young audiences and ironic uses. Klim, Aarhus, Denmark.

Povlsen, K. K. 2015. The older, the better: media and food preferences. In J. Leer and K. K. Povlsen, editors. Media food: politics, practices, and identities. Ashgate, Farnham, UK, in press.
Povlsen, K. K., U. G. Holst, and A. Poulsen. 2012. Kompleksitetsreduktion imedier: Tillid, trovardighed og økologiske fodevarer. Et litteratur review. Organic Eprints 20631, International Centre for Research in Organic Food Systems, Tjele, Denmark. [online] URL: http://orgprints.org/20631/2/20631.pdf

Prashant, K., and S. Harbir. 2009. Managing strategic alliances: what do we know now, and where do we go from here? Academy of Management Perspectives 23(3):45-62. http://dx.doi.org/10.5465/ AMP.2009.43479263

Prusak, L., and D. Cohen. 2001. How to invest in social capital. Harvard Business Review 79(6):86-93.

Reilly, J. 2006. Impact of media on food choice. Pages 201-226 in R. Shepherd and M. Raats, editors. The psychology of food choice. CABI, Cambridge, Massachusetts, USA. http://dx.doi. org/10.1079/9780851990323.0201

Rittenhofer, I. 2012. Ecology and trust in management and business research 1995-2010. Tentative findings. MultiTrust milestone paper. Organic Eprints 20781, International Centre for Research in Organic Food Systems, Tjele, Denmark. [online] URL: http:// orgprints.org/20781/4/20781.pdf

Roitner-Schobesberger, B., I. Darnhofer, S. Somsook, and C. R. Vogl. 2008. Consumer perceptions of organic food in Bangkok, Thailand. Food Policy 33(2):112-121. http://dx.doi.org/10.1016/j. foodpol.2007.09.004

Rosen, J. D. 2010. A review of the nutrition claims made by proponents of organic food. Comprehensive Reviews in Food Science and Food Safety 9(3):270-277. http://dx.doi.org/10.1111/ j.1541-4337.2010.00108.X

Rousseau, D. M., S. B. Sitkin, R. S. Burt, and C. Camerer. 1998. Not so different after all: a cross-discipline view of trust. Academy of Management Review 23(3):393-404. http://dx.doi.org/10.5465/ AMR.1998.926617

Sako, M. 1991. The role of 'trust' in Japanese buyer-supplier relationships. Ricerche Economiche 45(2-3):449-474.

Schrøder, K., K. Drotner, S. Kline, and C. Murray. 2003. Researching audiences: a practical guide to methods in media audience analysis. Arnold, London, UK.

Simmel, G. 1950. The sociology of Georg Simmel. K. H. Wolff, translator and editor. Free, New York, New York, USA.

Simmel, G. 1990. The philosophy of money. Routledge, London, UK.

Simmel, G. 2008. Gesamtausgabe 18: the sociology of secrecy and secret societies. Suhrkamp, Frankfurt am Main, Germany.

Smed, S., L. M. Andersen, N. Kærgård, and C. Daugbjerg. 2013. A matter of trust: how trust influence organic consumption. Journal of Agricultural Science 5(7):91-106. http://dx.doi. org/10.5539/jas.v5n7p91

Sodano, V., M. Hingley, and A. Lindgreen. 2008. The usefulness of social capital in assessing welfare effects of private and thirdparty certification food safety policy standards: trust and networks. British Food Journal 110(4-5):493-513. 
Sønderskov, K. M., and C. Daugbjerg. 2011. The state and consumer confidence in eco-labeling: organic labeling in Denmark, Sweden, the United Kingdom and the United States. Agriculture and Human Values 28:507-517. http://dx.doi. org/10.1007/s10460-010-9295-5

Stzompka, P. 1999. Trust: a sociologiocal theory. Cambridge University Press, Cambridge, UK.

Thøgersen, J. 2005. How may consumer policy empower consumers for sustainable lifestyles? Journal of Consumer Policy 28(2):143-177. http://dx.doi.org/10.1007/s10603-005-2982-8

Tulloch, J., and D. Lupton. 2003. Risk and everyday life. Sage, London, UK.

Ward, R., L. Hunnicutt, and J. Keith. 2004. If you can't trust the farmer, who can you trust? The effect of certification types on purchases of organic products. International Food and Agribusiness Management Review 7(1):60-77.

Yilmaz, A., and C. G. Atalay. 2009. A theoretical analyze on the concept of trust in organisational life. European Journal of Social Sciences 8(2):341-352.

Zachmann, K., and P. Østby. 2011. Food, technology, and trust: an introduction. History and Technology: An International Journal 27(1):1-10. http://dx.doi.org/10.1080/07341512.2011.548970

Zagata, L., and M. Lostak. 2012. In goodness we trust. The role of trust and institutions underpinning trust in the organic food market. Sociologia Ruralis 52(4):470-487. http://dx.doi. org/10.1111/j.1467-9523.2012.00574.X

Zaheer, A., and N. Venkatraman. 1995. Relational governance as an interorganizational strategy: an empirical test of the role of trust in economic exchange. Strategic Management Journal 16 (5):373-392. http://dx.doi.org/10.1002/smj.4250160504

Zanoli, R., and S. Naspetti. 2002. Consumer motivations in the purchase of organic food: a means-end approach. British Food Journal 104(8):643-653. http://dx.doi.org/10.1108/00070700210425930

Zorn, A., C. Lippert, and S. Dabbert. 2012. Supervising a system of approved private control bodies for certification: the case of organic farming in Germany. Food Control 25:525-532. http://dx. doi.org/10.1016/j.foodcont.2011.11.013 